\title{
Potential Combination of Kapok Leaf Extract (Ceiba pentandra G.) and Turmeric Extract (Curcuma domestica Va) as an Anticancer Compound
}

\author{
Muh. Natsir ${ }^{1 *}$, Sanang Nur Safitri ${ }^{1}$, Oktovia Nurmawati ${ }^{1}$, Muh. Saleh Purnama R. ${ }^{1}$, Ruslan $^{2}$ \\ ${ }^{1}$ Department of Chemistry, Faculty of Mathematics and Natural Sciences, Halu Oleo University \\ ${ }^{2}$ Department of Chemistry, Faculty of Mathematics and Natural Sciences, Tadulako University
}

\begin{abstract}
Combination of kapok leaf extract (Ceiba pertandra G.) and turmeric extract (Curcuma domestica Va.) was carried out to determine the potential of extracts in treating cancer with BSLT and murine cells P388. Cancer is a disease that is very feared because it's difficult to cure, and even rarely causes death. The sample was extracted with methanol, the extract was mixed so that the mixture extract from the two samples was obtained. The results showed that in the BSLT test the mixed extract had a bioactivity against shrimp larvae with an $\mathrm{LC}_{50}$ value of $142.946 \mathrm{ppm}$. While in Leukemia P388 cell testing showed that the combination of mixed extracts had a cytotoxic effect on Leukemia P388 cancer cells with inhibitory concentration values of $54.34 \mathrm{ppm}$. This shows that the kapok leaf extract (Ceiba pentandra G.) and combination of turmeric extract (Curcuma domestica Va.) has potential and can be developed as an anticancer agent because it has an $\mathrm{IC}_{50}$ value that can inhibit murine $\mathrm{P} 388$ cell growth and $\mathrm{LC}_{50}$ value which can kill shrimp larvae Artemia salina $\mathrm{L}$.
\end{abstract}

Keywords: Kapok Leaves, turmeric, cancer, BSLT, murine P388 cell

Abstrak. Kombinasi ekstrak daun kapuk (Ceiba pertandra G.) dan ekstrak kunyit (Curcuma domestica Va.) telah diilakukan untuk mengetahui potensi ekstrak dalam mengobati kanker dengan BSLT dan sel murine P388. Kanker merupakan penyakit yang sangat ditakuti karena sulit disembuhkan, bahkan jarang sekali menyebabkan kematian. Sampel diekstraksi dengan metanol, ekstrak dicampur sehingga diperoleh ekstrak campuran dari kedua sampel tersebut. Hasil penelitian menunjukkan bahwa pada uji BSLT ekstrak campuran memiliki aktivitas bioaktivitas terhadap larva udang dengan nilai LC 50 142,946 ppm, sedangkan pada pengujian sel leukemia P388 menunjukkan bahwa kombinasi ekstrak campuran memiliki efek sitotoksik terhadap sel kanker Leukemia P388 dengan nilai konsentrasi penghambatan 54,34 ppm. Hal ini menunjukkan bahwa ekstrak daun kapuk (Ceiba pentandra G.) dan kombinasi ekstrak kunyit (Curcuma domestica Va.) berpotensi dan dapat dikembangkan sebagai agen antikanker karena memiliki nilai $\mathrm{IC}_{50}$ yang dapat menghambat pertumbuhan sel murine P388 dan nilai LC $_{50}$ yang dapat membunuh larva udang Artemia salina L.

Kata Kunci: Daun kapuk, kunyit, kanker, BSLT, sel murine P388

Articel history: Received: April 2, 2021; Accpeted: April 16, 2021

Cite: Natsir, M., Safitri, S.N., Nurmawati, O., R, M.S.P., \& Ruslan. (2021). Potential Combination of Kapok Leaf Extract (Ceiba pentandra G.) and Turmeric Extract (Curcuma domestica Va) as an Anticancer Compound. KOVALEN: Jurnal Riset Kimia, 7(1): 72-76.

\section{INTRODUCTION}

Cancer is the second largest cause of death after cardiovascular disorders. Cancer or carcinoma is a disease caused by damage to the basic regulatory mechanism of cell behavior, specifically the mechanism of cell

\footnotetext{
* Corresponding author

E-mail: natsirsibali@yahoo.com
}

growth and change regulated by genes. New body tissue cells grow abnormally due to genetic mutations of cells, invade surrounding tissue, and metastasis (spread) to the body. The main cause of cancer is unknown, but it is suspected that the cause is genetic factors. The research of cancer concluded that $70-90 \%$ of cancers in humans are caused by 
environmental factors, such as food, alcohol consumption, air pollution, water, chemicals in the workplace, radiation and ultraviolet light (Miranti et al., 2014).

The discovery of drugs derived from plants continues and provides important direction to various pharmacological targets including cancer, malaria, metabolic diseases, cardiovascular disease and neurologic disorders (Balunas \& Kinghorn, 2005). Several studies have been carried out to find out various types of secondary metabolites found in several parts of kapok plants (Ceiba pentandra G.) including the leaves (Pratiwi, 2014). Methanol extract in leaves has high angiogenesis activity (Nam et al., 2003). Curcumin has potential in cancer treatment. Curcumin can inhibit breast development by inhibiting estrogen receptor activation (ER) by estrogen and is also able to inhibit the development of colon cancer cells (Liu \& Ho, 2018). This study aims to determine the potential of anti-cancer compound activity in a combination of turmeric extract (Curcuma domestica Va.) and leaf extract of kapok plants (Ceiba pentandra Gaertn.).

\section{MATERIAL AND METHODS}

\section{Materials}

The materials used in this study were include turmeric and kapok leaves, ethanol, shrimp larvae, murine P388 cells, Fetal Bovine Serum (FBS), and Dimetil Sulfoksida (DMSO).

\section{Procedure}

\section{Sample preparation}

100 gram samples of turmeric and kapok leaves are taken around Kendari City, Southeast Sulawesi.

\section{Preparation of kapok leaves and turmeric.}

The kapok leaves that have been taken, washed to remove the dirt in the sample, then dried and mashed using a blender to obtain fine powder. Meanwhile, turmeric samples are cut into small pieces, dried, then mashed using a blender to obtain fine powder. Each sample is stored in a beaker or container and ready to be extracted.

\section{Extraction of kapok leaves and turmeric.}

Extraction using ethanol $75 \%$ solvent, extraction carried out by maceration. Each vessel is added with $2500 \mathrm{~mL}$ ethanol, left for $2 \times 24$ hours. Then the residuals and extras are separated. Maceration was carried out 3 times with ethanol solvent.

\section{Toxicity test with BSLT method}

Toxicity tests were carried out on the eggs of $A$. salina which had hatched which was called nauplius. The shrimp larvae are ready to be tested by Brine Shrimp Lethality Test (BSLT), which is 48-hour-old larvae. The concentration of the test in this study for the mixture of kapok leaf extract and turmeric extract was 1000 ppm, 500 ppm, 100 ppm, 50 ppm, 25 ppm and 12.5 ppm. This study also made a concentration of 0 ppm as a control, without the addition of extract. Larvae are left to 24 hours, the number of dead larvae is calculated with the help of a magnifying glass (Setiawan et al., 2018). The parameters used were the number of dead larvae of $50 \%$ of the total test larvae. Then the $\mathrm{LC}_{50}$ value is calculated by entering the probit number $(50 \%$ mortality of test larvae).

\section{Activity test of combination of kapok leaf extract and turmeric in preventing cancer cells}

Testing of cytotoxic activity against murine P388 cells with MTT medium (Ernawati et al., 2014). Murine P388 cells in RPMI 1640 medium (with a concentration of $>106$ cells / $\mathrm{mL}$ ) from culture flask were inserted in a $15 \mathrm{~mL}$ 
centrifuge tube and centrifuged at a speed of 1200-1300 rpm for 5 minutes at room temperature. The supernatant was separated by a sterile Pasteur pipette and the precipitate was added with $1 \mathrm{~mL}$ FBS and $100 \mu \mathrm{L}$ DMSO mixed slowly and transferred in a $2 \mathrm{~mL}$ tube. Cells were then dissolved and centrifuged for separation. Subsequently the test material subculture was carried out.

\section{RESULT AND DISCUSSION}

\section{Result of Toxicity Test with BSLT Method}

Based on the data in Table 1 shows that the extract from a combination of kapok leaf extract and turmeric has bioactivity to shrimp larvae which is indicated by the $\mathrm{LC}_{50}$ (Lethal
Concentration 50\%) value of $142.946 \mathrm{ppm}$. This value indicates that at concentrations above the extract can kill shrimp larvae up to $50 \%$ of the population. The smaller the $L_{50}$ value of a sample, the higher the bioactivity (Pasilala et al., 2016).

According to Meyer et al. (1982) an extract is said to be toxic if it has an $L_{50}$ value $<1,000$ ppm and a pure compound is said to be toxic if it has an $\mathrm{LC}_{50}$ value $<30 \mathrm{ppm}$. Therefore, it can be said that the mixture of ethanol extract from kapok leaves and turmeric leaves is toxic because the $L_{50}$ value $<1,000$ ppm and has the potential as an anti-cancer agent.

Table 1. The results of the BSLT combination are kapok leaf extract and turmeric at same concentration

\begin{tabular}{ccccccc}
\hline $\begin{array}{c}\text { Concentration } \\
(\mathrm{ppm})\end{array}$ & $\begin{array}{c}\text { Concentration } \\
\text { Log }\end{array}$ & $\begin{array}{c}\text { Total Test } \\
\text { Larvae }\end{array}$ & $\begin{array}{c}\text { Number of } \\
\text { Dead } \\
\text { Larvae }\end{array}$ & $\begin{array}{c}\% \\
\text { mortality }\end{array}$ & $\begin{array}{c}\text { Probit } \\
\text { Value }\end{array}$ & LC $_{50}$ \\
\hline 0 & 0 & 10 & 0 & 0 & 0 & 0 \\
12.5 & 1.09 & 10 & 0 & 0 & 4.75 & 142.946 \\
25 & 1.39 & 10 & 4 & 40 & 6.25 & 5.39 \\
50 & 1.69 & 10 & 6 & 70 & 5.84 \\
100 & 2 & 10 & 7 & 80 & 6.28 \\
\hline 50 & 2.69 & 10 & 8 & 90 & \\
\hline
\end{tabular}

$\mathrm{LC}_{50}=$ Lethal Concentration $50 \%$.

\section{Activity Test Result of Combination of Kapok Leaf Extract and Turmeric in Preventing Cancer Cells}

The results of data analysis showed that $\mathrm{IC}_{50}$ (Inhibition Concentration) combination of ethanol extract of kapok leaves and turmeric leaves against Leukemia P388 cancer cells showed that the combination of ethanol extract of kapok leaves and turmeric had cytotoxic effects on P388 Leukemia cancer cells with inhibitory concentration values of 54.34 ppm (Table 2). These results indicate that the $\mathrm{IC}_{50}$ combination of ethanol extract of kapok leaves and turmeric leaves are quite active extracts. According to (Winarno et al., 2010), the greater the $\mathrm{IC}_{50}$ value, the more the compounds are not cytotoxic or the anti-cancer potential decreases. Based on this, the combination of ethanol extract from kapok leaves and turmeric has the potential to be anti-cancer. 
Table 2. Cytotoxic test results and $I_{50}$ values combination of ethanol extract of kapok leaves and turmeric against murine cells P388

\begin{tabular}{cccccc}
\hline \multirow{2}{*}{ Type of Extract } & $\begin{array}{c}\text { Concentration } \\
(\mathrm{ppm})\end{array}$ & \multicolumn{3}{c}{ Absorban } & \multirow{2}{*}{$\mathrm{C}_{50}$} \\
\cline { 3 - 5 } & 1000 & 0.012 & 0.003 & 0.02 & \\
\hline The & 500 & 0.051 & 0.156 & 0.387 & \\
combination of & 100 & 0.211 & 0.653 & 0.679 & \\
kapok leaf & 50 & 0.662 & 0.625 & 0.794 & 54.34 \\
extract and & 25 & 0.72 & 0.636 & 0.65 & \\
turmeric & 12.5 & 0.619 & 0.527 & 0.68 & \\
& 0 & 0.649 & 0.525 & 0.564 & \\
\hline
\end{tabular}

$\mathrm{IC}_{50}=$ Inhibition Concentration 50

\section{CONCLUSION}

Inhibition of murine cell growth P388 $50 \%\left(\mathrm{IC}_{50}\right)$ from a combination of turmeric extract (Curcuma domestica Va.) And kapok leaf extract (Ceiba pentandra G.) was 54.34 ppm and also the results of toxicity tests on Artemia salina $\mathrm{L}$. larvae with $\mathrm{LC}_{50}$ values 142.946 ppm. Based on these results it can be seen that the combination of turmeric extract (Curcuma domestica Va.) And kapok leaf extract (Ceiba pentandra G.) has potential and can be developed as an anticancer agent because it has an $\mathrm{IC}_{50}$ value that can inhibit murine P388 cell growth and $\mathrm{LC}_{50}$ values that can kill Artemia salina L. shrimp larvae.

\section{REFERENCES}

Balunas, M. J., \& Kinghorn, A. D. (2005). Drug discovery from medicinal plants. Life Sciences, $\quad 78(5), \quad 431-441$. https://doi.org/10.1016/j.Ifs.2005.09.012

Ernawati, T., Anita, Y., Lotulung, P. D., \& Hanafi, M. (2014). Synthesis of Methyl 2cinnamamido-3-hydroxy propanoate having activity against P388 leukemia cells. Journal of Applied Pharmaceutical Science, $\quad 4(3), \quad 92-95$. https://doi.org/10.7324/JAPS.2014.4031 8

Liu, H.-T., \& Ho, Y.-S. (2018). Anticancer effect of curcumin on breast cancer and stem cells. Food Science and Human Wellness, $\quad 7(2), \quad$ 134-137. https://doi.org/10.1016/j.fshw.2018.06.0 01

Meyer, B. N., Ferrigni, N. R., Putnam, J. E., Jacobsen, L. B., Nichols, D. E., \& McLaughlin, J. L. (1982). Brine shrimp: A convenient general bioassay for active plant constituents. Planta Medica, 45(5), 31-34. https://doi.org/10.1055/s-2007971236

Miranti, Yeni, L. F., \& Nurdini, A. (2014). Uji Potensi Anti Kanker Ekstrak Biji Pinang Merah dan Implementasinya dalam Pembelajaran Mitosis. Jurnal Pendidikan Dan Pembelajaran Khatulistiwa, 3(11), Article 11. https://jurnal.untan.ac.id/index.php/jpdp b/article/view/7656

Nam, N.-H., Kim, H.-M., Bae, K.-H., \& Ahn, B.Z. (2003). Inhibitory effects of Vietnamese medicinal plants on tube-like formation of human umbilical venous cells. Phytotherapy Research: PTR, 17(2), 107-111. https://doi.org/10.1002/ptr.934

Pasilala, F. B., Tarigan, D., \& Saleh, C. (2016). Uji Toksisitas (Brine Shrimp Lethality Test) Dan Aktivitas Antioksidan Dari Daun Sintrong (Crassocephalum crepidioides) Dengan Metode Dengan Metode 2,2-diphenyl-1-picrylhidrazil (DPPH). JURNAL KIMIA MULAWARMAN, 14(1). http://jurnal.kimia.fmipa.unmul.ac.id/inde x.php/JKM/article/view/253

Pratiwi, R. H. (2014). Potensi Kapuk Randu (Ceiba pentandra Gaertn.) Dalam Penyediaan Obat Herbal. E-Journal Widya Kesehatan dan Lingkungan, 1(1), 53-40. 
Setiawan, E., Nurhayati, A. P. D., de Voogd, N. J., Dewi, A. T., Alivy, A., Kartikasari, L., \& Subagio, I. (2018). Toxicity test of mangrove epibiont sponges in Tampora Situbondo using brine shrimp lethality test (BSLT). AIP Conference Proceedings, 2002(1), 020017. https://doi.org/10.1063/1.5050113

Winarno, E. K. W. K., Mazda, Rahmawati, H., \& Winarno, H. (2010). Pengaruh Iradiasi Gamma Pada Aktivitas Sitotoksik Daging Buah Mahkota Dewa (Phaleria macrocarpa (Scheff) Boerl.). Jurnal Sains dan Teknologi Nuklir Indonesia (Indonesian Journal of Nuclear Science and Technology), 11(2), 67-76. https://doi.org/10.17146/jstni.2010.11.2. 398 